\title{
Coping Strategies and Personality Traits in Women Patients with Migraine and Tension Type Headache
}

\author{
Osman Özdemir ${ }^{1}$, Fatma Aykan², Pınar Güzel Özdemir²
}

\section{ÖZET:}

Migren ve gerilim tipi bașag̃rısı olan bayan hastalarda kișilik özellikleri ve baș etme yöntemleri

Amaç: Stres ve anksiyete baș ag̃rılarının en sık tetikleyicileridir. Kişilik özellikleri ve başa çıkma yöntemleri bireylerin strese verdig̃i yanıtı etkiler. Yapılan çalışmalarda kaygılı ve depresif kişilik özelliklerinin başag̃rııına yatkınlık olușturabileceg̃ini, başag̃rısı olan hastaların işlevsel olmayan başa çıkma yöntemlerini daha sık kullandıklarını göstermiştir. Bu çalışmada migren ve gerilim tipi bașag̃rısı olan bayan hastalarda başa çıkma yöntemlerinin ve kişilik özelliklerinin incelenmesini amaçlamıştır.

Yöntem: Çalıșmaya 45 migren, 45 gerilim tipi baș ag̃rısı olmak üzere toplam 90 hasta ve 42 sag̃lıklı gönüllü alınmıştır. Katııımcılara Görsel Analog Skala, Başa Çıkma Tutumlarını Deg̃erlendirme ölçeg̃i (COPE), Eysenck kișilik anket / Revize Kısaltılmış Formu, Beck Depresyon Ölçeg̃ive Beck Anksiyete ölçeg̃i uygulanmıştır.

Bulgular: Migren ve gerilim tipi baș ag̃rısı olan hastalarda sag̃lıklı bireylere kıyasla anksiyete ve depresyon düzeylerinin daha yüksek oldug̃u bulundu. Ayrıca, bu hastaların kontrol grubuna göre daha yüksek nörotizm puanlarına sahip oldug̃u tespit edildi. Migren hastalarında COPE alt ölçeklerinden yararlı sosyal destek kullanımı puanlarının kontrol grubuna kıyasla daha düșük, dini olarak bașa çıkma düzeylerinin daha yüksek oldug̃u bulundu. Gerilim tipi baș ag̃rısı olan hastalarda ise aktif bașa çıkma puanlarının kontrol grubuna göre daha düşük oldug̃u bulundu.

Sonuç: Bu sonuçlar migren ve gerilim tipi baş ag̃rısı olan hastaların sag̃lıklı bireylerle karşılaştııılıõında aktif bașa çıkma yöntemleri daha az kullandıklarını, daha fazla nevrotik kişilik özelliklerine sahip olduklarını, ayrıca daha yüksek depresyon ve anksiyete düzeylerine sahip olduklarını göstermektedir. Sözkonusu etkenler başag̃rılarının bașlamasında, tetiklenmesinde ve șiddetinde önem tașıyabilir.

Anahtar sözcükler: stres, baș ag̃rısı, baş etme, kişilik özellikleri

Journal of Mood Disorders 2014;4(2):59-65

\section{ABSTRACT:}

Coping Strategies and personality traits in women patients with migraine and tension type headache

objective: Stress and anxiety are the most frequent triggers of headaches. Personality traits and coping strategies can affect the human stress response. Some studies demonstrated that certain personality traits may predispose to headaches and headache patients have less effective and more passive coping strategies. The present study aimed to examine coping strategies and personality types in women with migraine and tension type headache (TTH).

Methods: Participants were composed of 45 patients with migraine, 45 patients with TTH, and 42 healthy controls. Visual analogue scale (VAS), The COPE scale, Eysenck personality questionnaire Revised/Abbreviated Form (EPQR-A), Beck Depression Inventory (BDI) and Beck Anxiety Inventory (BAI) were administered to the participants.

Results: We found that patients with migraine and tension-type headache had higher levels of anxiety and depression than those of individuals without headache. Also, these patients had higher neuroticism scores than that of control subjects. Migraine patients scored lower for the use of instrumental social support subscale and higher for the religious coping subscale as determined by the COPE. Subjects with tension-type headaches showed lower on the active copingsubscale.

Conclusion: This study shows that patients with migraine and TTH had maladaptive and ineffective coping responses, and more neurotic personality features, when compared with healthy subjects. These factors may playa significant role in the development of headaches and their severity.

Key words: stress, headache, coping, personality traits

Journal of Mood Disorders 2014;4(2):59-65

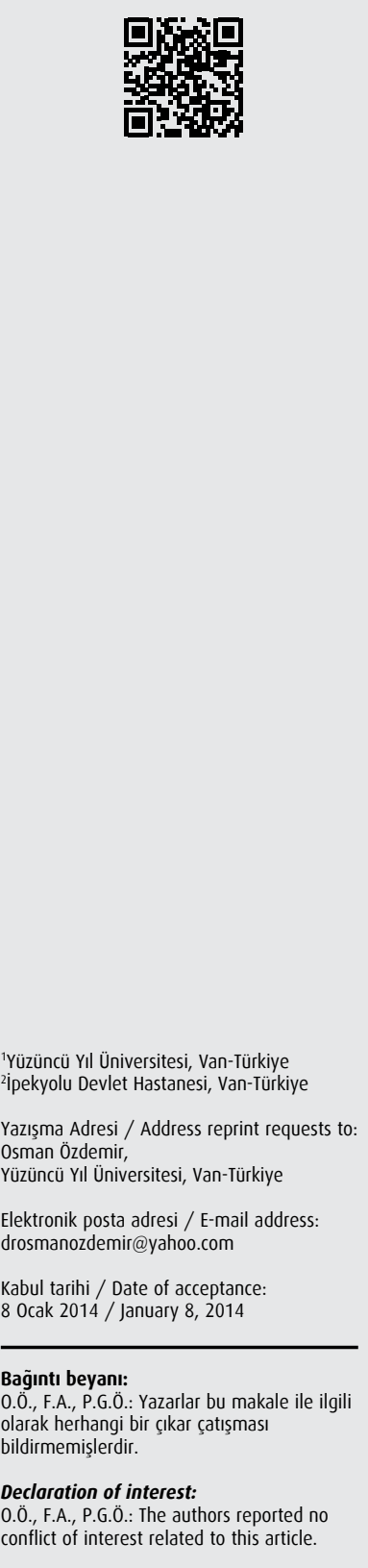




\section{INTRODUCTION}

Migraine and tension-type headache (TTH) are most common types of primary headaches(1). Migraine is a chronic neurological disorder characterized by recurrent moderate to severe headache attacks lasting from hours to days. Symptoms of migraine include the pain accompanied by nause, vomiting, phonophobia (increased sensitivity to noise), and photophobia (increased sensitivity to light) (2). There are many potantial migraine triggers including stres, hormone changes (menses, pregnancy), dietary habits (e.g. chese, chocolate, and nuts), hunger, travel, and poor sleep. TTH, previously called muscle contraction headache and stres headache, is characterized by generalized pressure or tightness in the head. There is usually mild to moderate pain which is unaffected by activity. In general, TTH is not associated with nausea, vomiting, photophobia, and phonophobia (3).

Patients with headache have significantly higher rates of psychiatric comorbidity (4). Stress and anxiety are also the most frequent triggers of headaches (5). The concept of stress is defined as the subjective reaction to a mentally or emotionally disruptive or upsetting situations. Feeling of stress is related to various dynamic processes of the interactions between person and his or her social and nature environment. Personality traits and coping strategies can affect the human stress response $(5,6)$. Coping is a complex, multidimensional, cognitive and behavioral response to manage the stressful conditions. The cope strategies which are influenced by personal, social, familial, work, and the environment factors can be categorized into several different types such as problemfocused coping strategies versus emotion-focused coping strategies, confrontation versus avoidance coping strategies, and active coping strategies versus passive coping strategies $(7,8)$. Problem-focused coping includes behavioral efforts to change or eliminate the stressor. Emotion-focused coping is the attempt to reduce the emotional impact of stres (8). Problem-focused coping, seeking advice from counselors and seeking social support, has been found to be positively related to mental health and well-being, while use of avoidance-oriented coping is an ineffective. It has been shown that headache patients have less effective and more passive coping strategies $(5,9)$. These findigs suggest that maladaptive cognitive processes can cause the persistent headache syndromes.

Personality can be defined as a person's characteristics accounting for relatively consistent patterns of thoughts, feelings, and behaviors (10). There are several model of conceptualizing personality. Eysenck developed three dimensional model of personality: psychoticism, extraversion, and neuroticism. Neuroticism is characterized by anxiety, depression, low self-esteem, and emotional instability. Extraversion is related to socialization, having many friends, impulsive and sometimes aggressive behaviors. Psychoticism is associated with genetic liability to psychosis, hostility, intolerance, and lack of empathy (11). In some studies, the authors demonstrated that certain personality traits might predispose to headaches $(5,9,12)$. For example in a study on the effect of personality traits on headache, paranoid and obsessive compulsive personality traits were found significantly higher in patients with headache than healthy control group (12). Another study reported that Negative Self-Concepts, Personal Maladjustment and Desire for Change and Giving up/Helplessness subscale scores of Automatic Thought Questionnire (ATQ) were significantly higher in TTH group than the control group (9). The present study aimed to examine COPE and personality types in women with migraine and TTH.

\section{PATIENTS AND METHODS}

\section{Patients}

The patients were 90 headache sufferers applied to the neurology outpatient clinic of the Ipekyolu Public Hospital. Participants were 45 migraine patients, 45 patients with TTH, and 42 healthy controls. The headache diagnoses were made according to the IHS (Internatonal Headaches Society, 2004) criteria. Since migraine and TTH are significantly more frequent in women than in man, only women were included in the study to avoid any gender specific possible effects. Patients with previously diagnosed cardiovascular, neurological, gynecological diseases, any major physical or mental illness and with substance abuse were excluded. The control group was recruited from hospital staff that has no complaint of headache and no history of psychiatric or medical illness. 
The study received approval from the University Ethical Committee. Written informed consent was obtained from the participants.

\section{Instruments}

Socio-demographic questionnaire, Visual analogue scale (VAS), The COPE scale, Eysenck personality questionnaire Revised/Abbreviated Form (EPQR-A), Beck Depression Inventory (BDI) and Beck Anxiety Inventory (BAI) were administered to the participants by a psychologist.

Socio-Demographic Questionnaire: The Sociodemographic questionnaire included questions about age, marital status, educational level, employment status, duration of headache.

Visual Analogue Scale (VAS): The Visual Analogue Scale (VAS) is an instrument commonly used to measure the pain level a patient feels. It is a horizontal line involving a number from 0 (no pain) to 10 (worst pain possible) (13).

The COPE Scale: The COPE scale (14) is a 60 -item selfreport measure designed to asses 15 coping strategies in stressful situations. Participants are instructed to indicate for each item, on a 4-point Likert scale ranging from 1 (I usually don't do this at all) to 4 (I usually do this a lot). The subscales of the COPE are as following; (1) positive reinterpretation and growth, (2) mental disengagement, (3) focus on venting of emotions, (4) use of instrumental social support, (5) active coping, (6) denial, (7) religious coping, (8) humor, (9) behavioral disengagement, (10) restraint, (11) use of emotional social support, (12) substance use, (13) acceptance, (14) supression of competing activities, and (15) planning. The validity and reliability Turkish version of this scale was demonstrated by Agargün et al. (15).

Eysenck Personality Questionnaire Revised/ Abbreviated Form (EPQR-A): The Revised- Abbrerviated version of the Eysenck Personality Questionnaire (EPQR-A, 15F) is a 24 items self-report questionnaire containing Extraversion (extraversion/introversion), Neuroticism (stability/emotionality), Psychoticism and Lie subscales, each contain 6 items. 60 The answer to a yes-no question is scored 1 or 0 , and a high scores show personality traits. It has been adapted and standartised for the Turkısh population (11).

Beck Depression Inventory (BDI): The Beck Depression Inventory (BDI) is a 21-item self-report measure of depressive symptom severity. Each item is rated on a $0-3$ and the total scores range from 0 to 63 , with higher values indicating more severe depressive symptoms. The validity and reliability Turkish version of the BDI was demonstrated by Hisli (16).

Beck Anxiety Inventory (BAI): The Beck Anxiety Inventory (BAI) consists of twenty-one items self-report used to assess emotional, physiological, and cognitive symptoms of anxiety (such as tingling or numbness, pounding heart, fear of dying). 64 Multiple choices questions have four possible answers: not at all (0 points), mildly ( 1 points), moderately ( 2 points), and severely ( 3 points). The test scores range between 0 and 63. The validity and reliability Turkish version of the BAI was performed by Ulusoy (17).

\section{Statistical Analysis}

Descriptive statistics for studied variables (characteristics) were presented as mean and standard deviation. One-way ANOVA test was used to compare control and patient groups for the studied variables. After ANOVA test, Duncan multiple comparison test was employed to determine different groups. Statistical significance levels were considered as $5 \%$. The SPSS (ver. 13) statistical program was used for all statistical computations.

\section{RESULTS}

The age, Visual Analogue Scale (VAS), Beck Depression Inventory (BDI), and Beck Anxiety Inventory (BAI) for each group are presented in Table 1 . The ages of participants were between 18 to 40 , the mean age for the migraine, TTH, and control groups were $30.71 \pm 6.18$, $24.73 \pm 6,43$, and $25.28 \pm 6.13$ years respectively. The mean age of the migraine group was significantly higher than that of the TTH and control groups. There was no statistically significant difference in the VAS, BDI and BAI 
Table 1: The age, VAS, BDI, and BAI scores for groups

\begin{tabular}{lccccc} 
Groups & Migraine & ITH & Control & F & P \\
\hline Age & $30.71 \pm(6.18)^{\mathrm{a}}$ & $24.73 \pm(6.43)^{\mathrm{b}}$ & $25.28 \pm(6.13)^{\mathrm{b}}$ & 12.43 & 0.00 \\
VAS & $8.93 \pm(1.45)^{\mathrm{b}}$ & $8.28 \pm(1.7)$ & - & 0.46 & 0.06 \\
BDI & $17.75 \pm(9.74)^{\mathrm{a}}$ & $21.60 \pm(9.27)^{\mathrm{a}}$ & $12.76 \pm(9.05)^{\mathrm{b}}$ & 9.69 & 0.00 \\
BAI & $23.46 \pm(11.32)^{\mathrm{a}}$ & $25.60 \pm(11.95)^{\mathrm{a}}$ & $13.16 \pm(10.83)^{\mathrm{b}}$ & 14.64 & 0.00 \\
\hline
\end{tabular}

VAS: Visual Analogue Scale, BDI: Beck Depression Inventory, BAI: Beck Anxiety Inventory

$\rightarrow{ }^{\mathrm{a}, \mathrm{b}}$ : Different lower casesindicate statistically significant difference among groups' mean

Table 2: The COPE scale and The Eysenck Personality Questionnaire scores for each group

\begin{tabular}{|c|c|c|c|c|c|c|c|c|}
\hline Groups & Migraine & SD & TTH & SD & Control & SD & $\mathbf{F}$ & $\mathbf{p}$ \\
\hline \multicolumn{9}{|l|}{ COPE Scale } \\
\hline Positive reinterpretation and growth & 11.97 & 2.80 & 11.17 & 3.10 & 12.54 & 3.76 & 1.97 & 0.14 \\
\hline Mental disengagement & 9.62 & 2.43 & 9.97 & 2.61 & 9.90 & 2.42 & 0.25 & 0.77 \\
\hline Focus on and venting of emotions & 11.20 & 3.51 & 11.60 & 2.69 & 12.07 & 2.34 & 0.98 & 0.37 \\
\hline Use of instrumental social support & $10.24^{\mathrm{a}}$ & 3.42 & $11.15^{\mathrm{ab}}$ & 3.12 & $12.11^{\mathrm{b}}$ & 3.09 & 3.67 & 0.02 \\
\hline Active coping & $10.93 a^{b}$ & 3.23 & $10.02^{\mathrm{a}}$ & 2.80 & $11.30^{\mathrm{b}}$ & 2.43 & 2.36 & 0.04 \\
\hline Denial & 7.71 & 2.71 & 8.00 & 2.76 & 7.14 & 2.59 & 1.13 & 0.32 \\
\hline Religious coping & $14.68^{\mathrm{a}}$ & 2.35 & $14.28^{\mathrm{ab}}$ & 2.15 & $13.38^{\mathrm{b}}$ & 3.34 & 2.75 & 0.03 \\
\hline Humor & 7.00 & 3.09 & 7.22 & 2.96 & 8.04 & 2.86 & 1.47 & 0.23 \\
\hline Behavioral disengagement & 8.28 & 3.08 & 9.26 & 3.34 & 8.00 & 2.44 & 2.16 & 0.11 \\
\hline Restraint & 10.55 & 3.33 & 10.82 & 2.67 & 10.21 & 1.80 & 0.55 & 0.57 \\
\hline Use of emotional social support & 11.35 & 3.14 & 11.35 & 3.22 & 12.42 & 2.88 & 1.72 & 0.18 \\
\hline Substance use & 5.08 & 2.29 & 5.15 & 2.29 & 5.92 & 2.68 & 1.59 & 0.20 \\
\hline Acceptance & 10.57 & 3.57 & 10.53 & 3.04 & 9.85 & 2.29 & 1.76 & 0.46 \\
\hline Suppression of competing activities & 10.33 & 2.51 & 10.13 & 2.68 & 10.50 & 1.90 & 0.25 & 0.96 \\
\hline Planning & 11.37 & 3.29 & 2.68 & 2.91 & 11.21 & 2.72 & 0.33 & 0.77 \\
\hline \multicolumn{9}{|l|}{ Eysenck Personality Inventory } \\
\hline Neuroticism & $4.64^{\mathrm{a}}$ & 1.70 & $4.22^{\mathrm{a}}$ & 1.83 & $3.47^{\mathrm{b}}$ & 1.75 & 4.84 & 0.009 \\
\hline Extraversion & 3.22 & 1.73 & 3.08 & 1.85 & 3.21 & 1.64 & 0.08 & 0.922 \\
\hline Psychoticism & 1.40 & 1.85 & 1.60 & 1.60 & 1.59 & 1.10 & 0.43 & 0.651 \\
\hline Lie & $4.88^{\mathrm{a}}$ & 1.02 & $5.02^{\mathrm{a}}$ & 1.21 & $4.00^{\mathrm{b}}$ & 1.76 & 7.46 & 0.001 \\
\hline
\end{tabular}

scoresbetween migraine and TTH patients. It was found that the means of both BDI and BAI scores were significantly higher in patients with headache than those of the control group.

Table 2 presents the four scales of the RevisedAbbrerviated version of the Eysenck Personality Questionnaire (EPQR-A) and the subscales of the COPE for each group. Post-hoc comparison tests indicated that patients with both migraine and TTH had significantly higher scores than the control group on the neuroticism $(\mathrm{F}=4.84, \mathrm{p}=0.009)$ and the lie scales $(\mathrm{F}=7.46, \mathrm{p}=0.001)$. The scores of the migraine group on "use of instrumental social support" were significantly lower than those of the TTH and control groups ( $F=3.67, p=0.02)$. Patients with migraine type headache scored significantly higher on the COPE subscale "religious coping" than that of the
TTH and control groups $(\mathrm{F}=2.75, \mathrm{p}=0.03)$. Subjects with tension type headache scored significantly lower for the "active coping" compared to that of the migraine and control groups $(\mathrm{F}=2.39, \mathrm{p}=0.04)$.

\section{DISCUSSION}

We found that patients with migraine and tensiontype headache have higher symptom level of anxiety and depression than those of individuals without headache. Also, these patients have higher neuroticism scores than that of control group. Migraine patients had a lower level of use of instrumental social support scale of the COPE and a higher level of religious coping. Subjects with tension-type headaches showed lower on the active copingsubscale. Results from this study support that 
patients with headache have maladaptive coping skills. It is known that coping strategies can contribute to a more severe course of the headaches (5). The coping strategies to stressful experiences may be important for buffering, reducing or eliminating the pain $(5,7)$. Some studies indicate that the effectiveness of coping strategies used is associated with decreased pain intensity, disability, depression, as well as increased physical and psychological functioning among headachepatients (7).

It has been shown that people often attribute their successes to internal or personal factors, but attribute their failures to external or situational factors leading to avoidance and escapist responses which may cause the onset or symptoms exacerbation (18). There are the engagement and disengagement dimensions of coping strategies. Engagement strategies include appraisal and active coping to manage stress. Appraisals are associated with increased engagement coping and less use of disengagement coping and physical symptoms $(19,20)$. In this study, patients with tension type headache did show significant lower scores on active coping when they were compared to migraine and control groups. Active coping such as active problem solving, planning, reconceptualize, and self-reliance strategies, are better ways to deal with stressful events, and avoidant coping strategies such as withdrawal, alcohol or drug use, lead to adverse effects involving headaches to stressful situations $(21,22)$.

It has been demonstrated that patients with migraine and TTH have increased vulnerability to stress, ineffective coping strategies, and high levels of anxiety and depression $(5,9,23)$. Siniatchkin et al. suggest that psychological factors are important for exacerbation or chronificationof headaches (5). They demonstrated a less adaptive coping strategies, elevated anxiety, depression and lower quality of life among headache patients. Yavuz et al. examined dysfunctional cognitive contents, processes and attitudes in patients with migraine, tension type headacheand control group. The results showed that patient groups had significantly higher levels of negative cognitive contents such as magnification and helplessness, which can explain the high prevalence of depression than healthy controls (9). Wieser et al. investigated painrelated cognition and coping in patints with migraine and tension type headache. They found that headache sufferers often used dysfunctional coping strategies like fear and avoidance (23).
In the present study, we found that migraine patients exhibited a significantly reduced use of instrumental social support. Several studies indicated that social support could help individuals to reduce the amount of stress experienced as well as to protect the harmful effects of stress on physical and mental health (24-26). Yasin and Dzulkifli examined the relationship between social support and psychological problems such as stress, depression and anxiety among undergraduate students (24). The study results revealed a negative relationship between social support and psychological problem. Social support could reduce the effect of stressors on psychological well-being and somatic complaints. The authors argued that it might be related to appraisal of effective problem-focused coping strategies. The proposed plan can be implemented the following assessment process of actually available resources for dealing with stress. Siedlecki et al. investigated the relationships among types of social support and different aspects of subjective well-being (i.e., positive and negative affect, life satisfaction) in a sample of adults between the ages of 18 and 95 years. They found that enacted or perceived support predicted life satisfaction, provided support predicted positive affect, and perceived support predicted negative affect. Perceived helpfulness and impact of social support from peers, family members, friends and community provide an emotional support including positive effects on feeling of distress, depression anxiety and other emotional states (25).

The comorbidity of depressive and anxiety disorders in patients with primary headache disorders, especially migraine and tension type headache, is previously well established $(27,28)$. Tan et al. found the high levels of depression and anxiety in both migraine and TTH patients. The incidences of depression, anxiety and depression+anxiety were $37.3 \%, 15.7 \%$ and $9.8 \%$, respectively, in migraine patients and $43.2 \%, 9.1 \%$ and $6.8 \%$, respectively, in TTH patients (27). Yücel et al. evaluated depressive automatic thoughts, alexithymia, and assertiveness in patientswith tension-type headache and in healthy controls. The headache patients had significantly higher scores on measures of depression, automatic thoughts, and alexithimia, and lower scores on assertiveness. Chronic headache sufferers had higher depression and automatic thoughts scores than subjects with episodic tension-type headache (28). Our results 
confirmed the presence of the depressive and anxiety symptoms among patients with migraine and TTH. The mean BDI, BAI scores of both headaches types were significantly higher than the control group. Depression and anxiety, either associated or not with pain, can lead to feeling powerless, passive attitude, low self-esteem, and inadequately managed pain $(27,29)$. These disorders can make people more sensitive to pain and its negative effects.

The personality traits of an invididual may also contribute to pain responses. Subjects with high levels of neuroticism (high emotional sensitivity and reactivity) have greater sensitivity to body sensations, fear of pain, more catastrophic cognitions, avoidance safety behaviors, feelings of helplessness, and ultimately to an important role in the onset, maintanence exacerbations or severity of pain and poorer adjustment $(7,27)$. Migraine and

\section{References:}

1. Khil L, Pfaffenrath V, Straube A, Evers S, Berger K. Incidence of migraine and tension-type headache in three different populations at risk within the German DMKG headache study. Cephalalgia. 2012;32:328-36.

2. Kelman L, Tanis D. The relationship between migraine pain and other associated symptoms. Cephalalgia. 2006;26:548-53.

3. Farooq K, Williams P. Headache and chronic facial pain. Continuing Education in Anaesthesia Critical Care and Pain. 2008;8:138-42.

4. Lake AE, Rains JC, Penzien DB, Lipchik GL. Headache and psychiatric comorbidity: Historical context, clinical implications, and research relevance. Headache. 2005;45:493-506.

5. Siniatchkin M, Riabus M, Hasenbring M. Coping styles of headache sufferers. Cephalalgia. 1999;19:165-73.

6. Stronks DL, Tulen JHM, Pepplinkhuizen L, Verheij R, Mantel GWH, Spinhoven P, et al. Personality traits and psychological reactions to mental stress of female migraine patients. Cephalalgia. 1999;19:566-74

7. Feirrea-Valente MA, Pais-Ribeiro JL, Jensen MP. Coping, Depression, Anxiety, Self-Efficacy and Social Support: Impact on Adjustment to Chronic Pain. Escritos de Psicología. 2009;2:8-17.

8. Sonnentag S, Frese M. Stress In Organızatıons.. Comprehensive Handbook of Psychology,2012.

9. Yavuz KF, Yavuz N, Ulusoy S, Alnıak I, Güneş HNG. Maladaptive Cognitive Content and Attitudes Accompanying Tension Type Headache and Migraine. Düşünen Adam: The Journal of Psychiatry and Neurological Sciences. 2013;26:12-21.

10. Özdemir O, Özdemir PG, Kadak MT, Nasıroğlu S. Personality Development. Current Approaches in Psychiatry. 2012;4:566-89. tension type headache sufferers are often neurotic, anxious, depressed and hypochondriac, or as resentful, hostile, and rigid $(6,30,31)$. This study is consistent with the literature showing associations between migraine, TTH and neuroticism.

In conclusion, this study showsthat patients with migraine and TTH have maladaptive coping strategies, also have an escapist, more neurotic personality, higher levels of depression and anxiety when compared with healthy subjects. These ineffective responses to stressful events may play a role in the development of migraine and TTH.

This study has many limitations. First, only women were included in the study. Second, the control group was recruited from hospital staff. Third, our sample size was relatively small; thus, our findings need replication inlargersamples.

11. Karanci N, Dirik G, Yorulmaz O. Reliability and validity studies of Turkish translation of eysenck personality questionnaire revisedabbreviated. Turkish Journal of Psychiatry. 2007;18:254-61.

12. Tamgaç A, Maner F, Gökalp PG, Öztürk M, Altunkaynak Y. Migren ve gerilim tipi baș ağrısı hastalarında kișilik örüntüsü. Düșünen Adam: The Journal of Psychiatry and Neurological Sciences. 2007;20:5-15.

13. Wewers ME, Lowe NK. A Critical-Review of Visual Analog Scales in the Measurement of Clinical Phenomena. Res Nurs Health 1990;13:227-36.

14. Carver CS. You want to measure coping but your protocol's too long: Consider the brief COPE. Int J Behav Med. 1997;4:92-100

15. Ağargün MY, Beşiroğlu L, Kıran UK, Ozer OA, Kara H. The psychometric properties of the COPE inventory in Turkish sample: a preliminary research. Anatolian Journal of Psychiatry. 2005;6:221-6.

16. Hisli N. Beck depresyon envanterinin üniversite öğrencileri için geçerliliği ve güvenirligi. Psikoloji Dergisi. 1989;7:3-13. (Article in Turkish)

17. Ulusoy S, Sahin NH, Erkmen H. Turkish version of the Beck Anxiety Inventory: Psychometric properties. J Cogn Psychother. 1998;12:163-72.

18. Ohtsuka K, Hyam P. Internal and external attribution of success and failure in gambling and nongambling situation. The proceedings of the 12th Annual National Association for Gambling Studies Conference. 2002; Melbourne.

19. Bandura A. Exercise of personal agency through the selfefficacy mechanism. Self-efficacy: Thought control of action. 1992;Hemisphere, Washington DC. 
20. Jerusalem M, Schwarzer R. Self-efficacy as a resource factor in stress appraisal processes. Self-efficacy: Thought control of action, 1992;Hemisphere,New York.

21. Khawaja NG. An investigation of the factor structure and psychometric properties of the COPE Scale with a Muslim immigrant population in Australia. Journal of Muslim Mental Health. 2008;3:1-15.

22. Holahan CJ, Moos RH. Risk, Resistance, and Psychological Distress - a Longitudinal Analysis with Adults and Children. J Abnorm Psychol. 1987;96:3-13.

23. Wieser T, Walliser U, Womastek I, Kress HG. Dysfunctional coping in headache: Avoidance and endurance is not associated with chronic forms of headache. Eur J Pain. 2012;16:268-77.

24. Yasin MAS, Dzulkifli MA. The relationship between social supports and psychological problems among students. International Journal of Business and Social Science. 2010;3:110-6

25. Siedlecki KL, Salthouse TA, Oishi S, Jeswani S. The Relationship Between Social Support and Subjective Well-Being Across Age. Soc Indic Res. 2013:1-18.
26. Ozbay F, Johnson DC, Dimoulas E, Morgan C, Charney D, Southwick S. Social support and resilience to stress: from neurobiology to clinical practice. Psychiatry (Edgmont). 2007;4:3540.

27. Tan FU, Ozen NE, Kazezoglu S, Kokoglu F, Boratay C. Depression and anxiety in patients with migraine and tension-type headache. Gazi Medical Journal. 2005;16:74-9.

28. Yucel B, Kora K, Ozyalcin S, Alcalar N, Ozdemir O, Yucel A. Depression, automatic thoughts, alexithymia, and assertiveness in patients with tension-type headache. Headache. 2002;42:194-9.

29. VonKorff M, Simon G. The relationship between pain and depression. Brit J Psychiat. 1996;168:101-8.

30. Cao M, Zhang SY, Wang KY, Wang YH, Wang W. Personality traits in migraine and tension-type headaches: A five-factor model study. Psychopathology. 2002;35:254-8.

31. Chen W, Yu S, Zhu J, Chai H, He W, Wang W. Personality Characteristics of Male Sufferers of Chronic Tension-Type and Cervicogenic Headache. J Clin Neurol. 2012;8:69-74. 